\title{
Surgical Treatment of a Rare "Reverse" Madelung Deformity in 11 Years Female Patient
}

\author{
Alexandru Ulici ${ }^{1,2}$, Daniel Catalin Florea', Iulia Tevanov', Dan Zaharie', Madalina Carp ${ }^{1}$ \\ ${ }^{1}$ Grigore Alexandrescu Emergency Hospital for Children, Bucharest, Romania \\ ${ }^{2}$ Carol Davila University of Medicine and Pharmacy, Bucharest, Romania
}

\author{
Corresponding author: \\ Alexandru Ulici, MD \\ 6 , lancu de Hunedoara Boulevard \\ BI H4, Sc1, et 1, ap 5, district 1 \\ Bucharest, Romania \\ E-mail: alexandruulici@me.com
}

\author{
Rezumat \\ Tratamentul chirurgical al unei paciente cu o formă rară de diformitate Madelung \\ „inversă"
}

Maladia Madelung reprezintã o deformare în porțiunea distalã a antebrațului ca urmare a unei tulburãri de dezvoltare la nivelul cartilajului de creştere distal radial, în urma cãreia se produce o înclinare ulnarã şi volarã a suprafeței articulare radiale, asociatã de cele mai multe ori cu subluxația dorsalã a ulnei. Este o afecțiune foarte rarã ce reprezintã 1,7\% din totalul malformatiilor mâinii fiind caracterizatã de prezența unei structuri anatomice, ligamentul Vickers, ce uneşte porțiunea distalã a radiusului cu osul semilunar al carpului. Deşi este consideratã a fi congenitalã, simptomatologia este absentã pânã în perioada pubertãții. Vã prezentãm cazul unei paciente în vârstã de 11 ani, ce s-a prezentat în clinica noastrã cu o deformare la nivelul ambelor antebrațe, ce consta într-o încurbare radialã cu convexitatea anterioarã, proeminentã volarã e epifizei ulnare, limitarea parțialã a supinației şi durere la nivelul articulației radiocarpiene. Deformarea a fost observatã de cãtre mamã în urmã cu un an, durerea apãrând în ultimele 6 luni. Mama pacientei, la vârsta de 13 ani, a fost diagnosticatã $\mathrm{cu}$ aceeaşi malformație, pentru care s-a intervenit chirurgical la acea vreme. Deasemenea trebuie mentionat faptul cã sora pacientei nu prezintã aceasta deformare. La examenul radiologic s-a constatat accentuarea înclinãrii ulnare a suprafeței articulare radiale şi luxația anterioarã a extremitãții distale a ulnei. Având în vedere deformarea cât şi prezența simptomatologiei dureroase, s-a luat decizia unei intervenții chirurgicale ce a constat în excizia ligamentului Vickers şi osteotomia de deschidere şi derotare a radiusului.

Cuvinte cheie: diformitate Madelung, ligament Vickers, osteotomie de radius

\section{Abstract}

Madelung deformity is an abnormality of the distal part of the forearm due to a growth arrest in the distal radial physis creating an increase of the radial tilt angle associated with a dorsal subluxation of the distal ulna in most cases. It 
is a rare condition which represents only $1.7 \%$ of hand deformities being characterized by the presence of an abnormal structure, Vickers ligament, that tethers the distal radius to the lunate bone. Although it is believed to be a congenital disorder, the symptoms are absent till late childhood. We present a case of a 11 years old girl patient, who came to our clinic for deformity of both forearms, which consisted of an anteriorly curved radius, volar proeminence of the distal ulna, partial limitation of supination and pain in the last 6 months, with and insidious onsed and aggravated lately. The mother of the patient, at the age of 13, was diagnosed with the same deformity which was surgically treated at that time. Furthermore, the patient has an older sister with no deformity of the forearms. X-rays revealed an increased radial tilt and anterior luxation of the distal ulna. Considering the deformity and the presence of pain we decided to excise the Vickers ligament and make an opening and derotation wedge osteotomy of the distal radius.

Key words: Madelung deformity, Vickers ligament, radius osteotomy

\section{Introduction}

Madelung deformity is an abnormality of the distal part of the forearm due to a growth arrest in the distal radial physis creating an increase of the radial tilt angle associated with a dorsal subluxation of the distal ulna in most cases. It is a rare condition which represents only $1.7 \%$ of hand (1) deformities being characterized by the presence of an abnormal structure, Vickers ligament, that tethers the distal radius to the lunate bone. This ligament is believed to impede the growth of the ulnopalmar aspect of the distal radius. Although it is believed to be a congenital disorder, the symptoms are absent till late childhood. The deformity is frequently associated with Leri-Weill dyscondrosteosis, the most common form of mesomelic dwarfism. It consists of short stature, shortness of the middle segment of the upper and lower extremities, and Madelung deformity $(1,2,3)$.

There are several hundred cases of Madelung deformity that have been presented in the literature since its first description but no published reports exist on the actual frequency of Madelung deformity in the population (4). In most cases, patients present whit a short forearm, loss of supination of the forearm, reduced wrist mobility, and dorsal proeminence of the distal ulna (5). A reverse Madelung deformity is also described in the literature where the growth disturbance in the ulnar portion of the distal radial epiphysis is posterior rather than anterior and the typical radial bow is reversed, which leads to volar dislocation of the ulna and dorsal displacement of the hand (6).

\section{Case report}

We present a case of a 11 years old girl patient, who came to our clinic for deformity of both forearms, which consisted of an anteriorly curved radius, increased ulnar deviation of the wrist, volar proeminence of the distal ulna, partial limitation of supination, 30 degrees (85 degrees normal) and pain in the last 6 months, with and insidious onsed and aggravated lately. She had bilateral shorten forearm and partial limitation of wrist flexion, 35 degrees (75 degrees normal). The mother of the patient, at the age of 13 , was diagnosed with the same deformity which was surgically treated at that time. Furthermore, the patient has an older sister with no deformity of the forearms.

$\mathrm{X}$-rays revealed an increased bilateral radial tilt (Fig.1), 42 degrees for the left forearm and 45 degrees for the right forearm (21-25 degrees normal), negative volar tilt, -32 degrees for the left forearm and -37 degrees for the right forearm $\left(+2^{-}\right.$ 20 degrees normal), anteriorly luxation of the distal ulna and anteriorly curved radius.

Evidence of the Vickers ligament was seen on the X-rays, there was a small spur on the ulnar side of the distal end of the radius and a fossalike origin distal to the spur (Fig. 2).

We also took a CT-scan where the deformity was seen better tridimensional.

Due to the presence of the pain we decided to perform an opening and derotation wedge osteotomy of the left distal radius (Fig. 3).

With the patient in dorsal decubitus postion and with the hand in supination on hand table we used volar (Henry) approach to wrist. After identifying the flexor carpi radialis tendon, the radial artery and the median nerve we retracted the first two radially and the last one ulnary. By dissection through the floor of the flexor carpi radialis tendon we identified the flexor palmaris longus and retracted it ulnary to protect the median nerve. After that we exposed the pronator quadratus and incised the radial border of the pronator quadratus. The Vickers ligament was observed and excised from the origin on the radial side to its insertion on lunate bone (Fig. 4). 


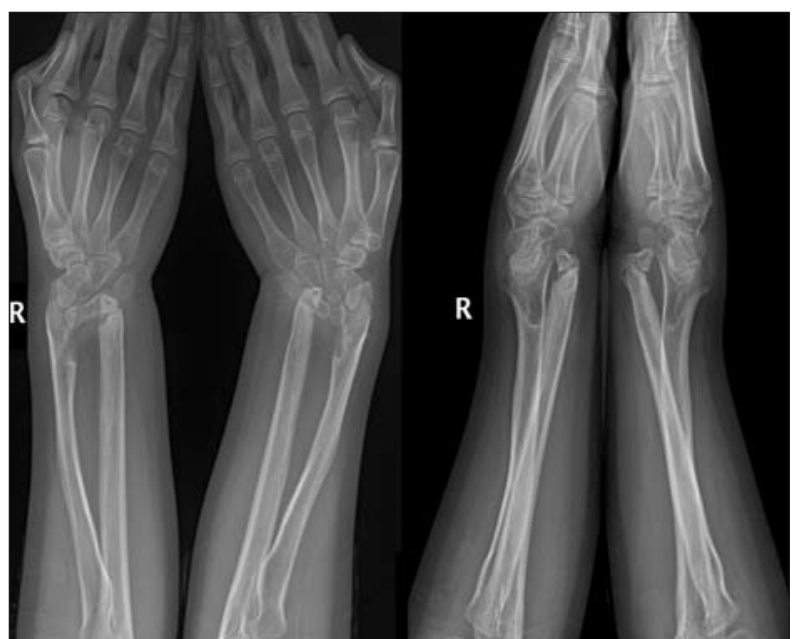

Figure 1. X-ray of the both forearms revealing the deformity

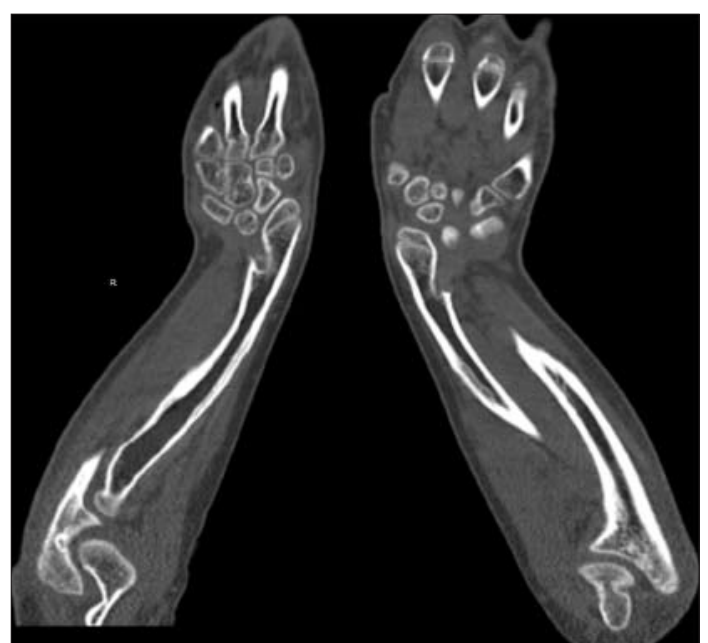

Figure 2. The spur and the fossalike origin of Vickers ligament

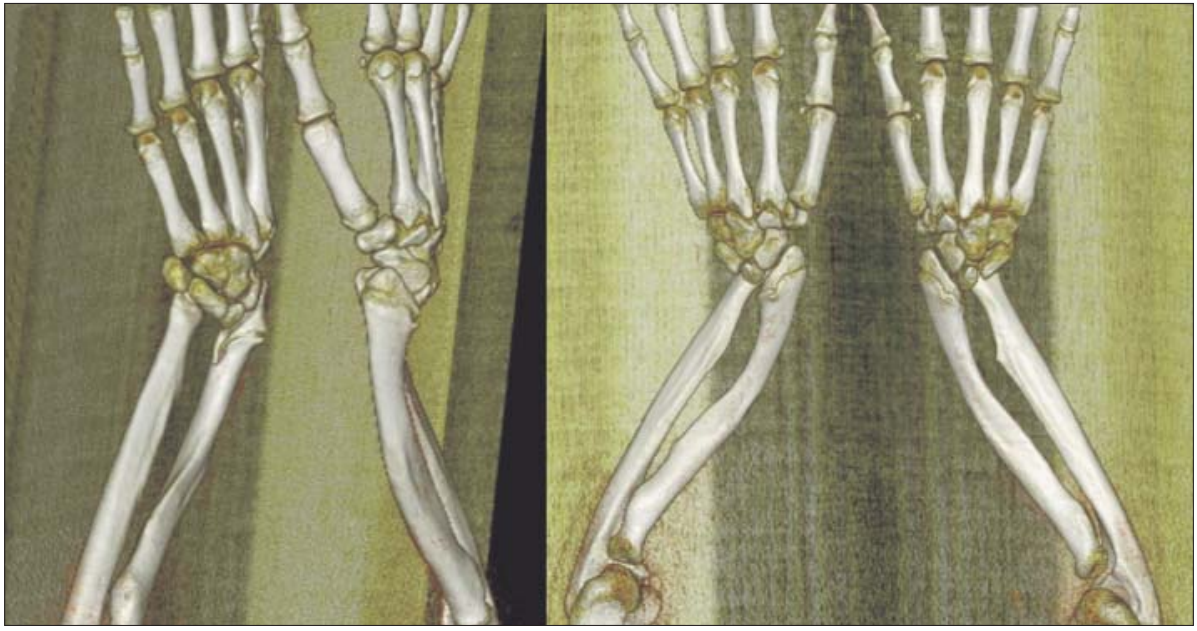

Figure 3. 3D reconstruction of the deformity

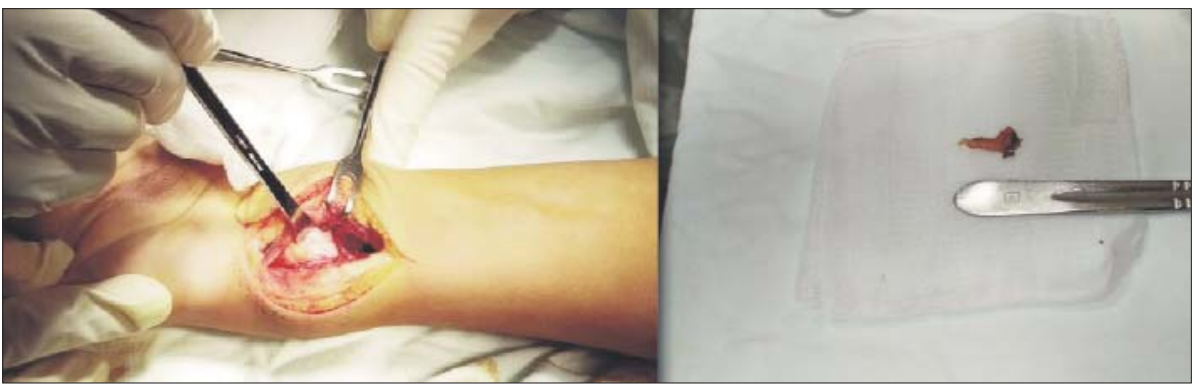

Figure 4. Vickers ligament

We continued with an posterior-medial opening and derotation wedge osteotomy of the distal radius and used a pre-curved distal radius plate and 6 screws for fixation (Fig. 5).

The pronator quadratus was repaired loosely with absorbable sutures and we closed the subcutaneous tissue and the superficial skin. Sterile dressing and a cast above the elbow with the forearm in full supination was applied. The cast was shortened after 4 weeks to a cast below the 


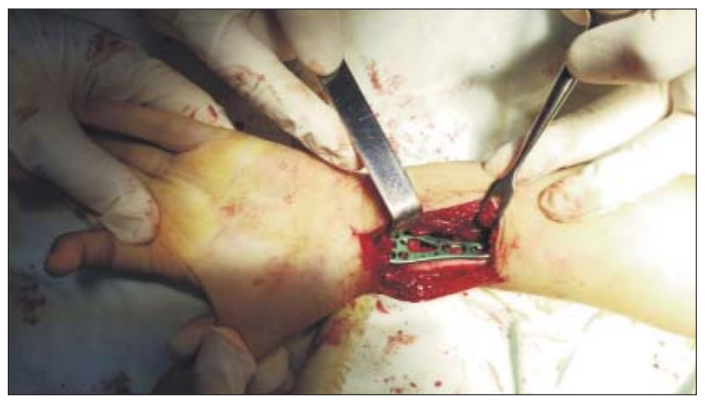

Figure 5. Material of osteosynthesis

elbow which was removed completely after another 2 weeks. At two month after the surgery we observed an increase of wrist flexion up to 50 degrees, increase of supination up to 70 degrees, the absence of pain and a very good cosmetic result (Fig. 7). Due to the good surgical result we proceeded with the same surgical intervention at the right forearm, also with very good results (Fig. 8).
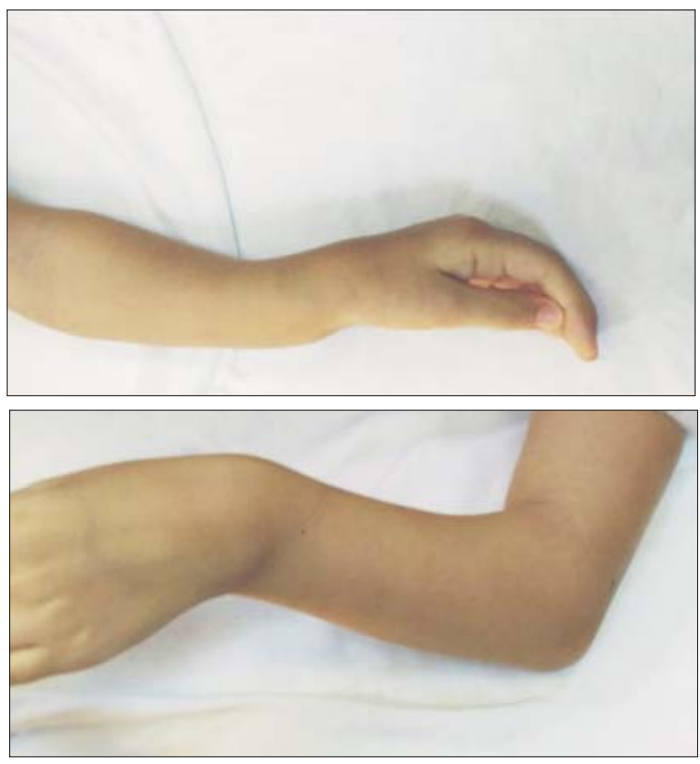

Figure 6. Left hand preoperative

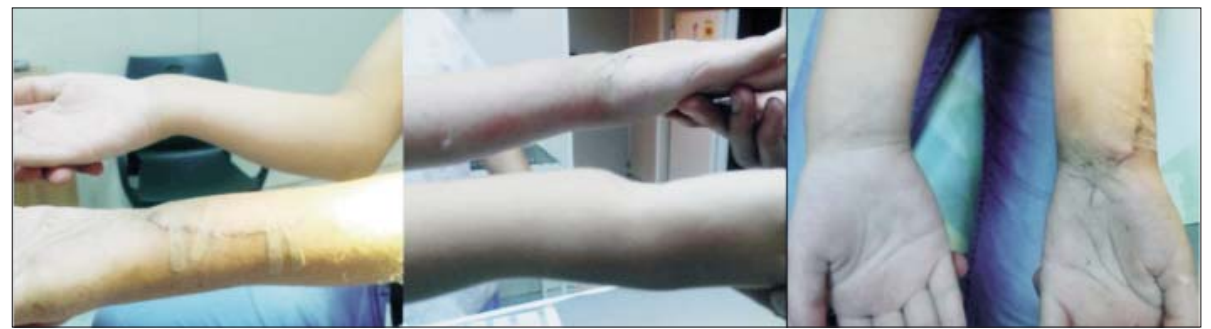

Figure 7. Left hand postoperative

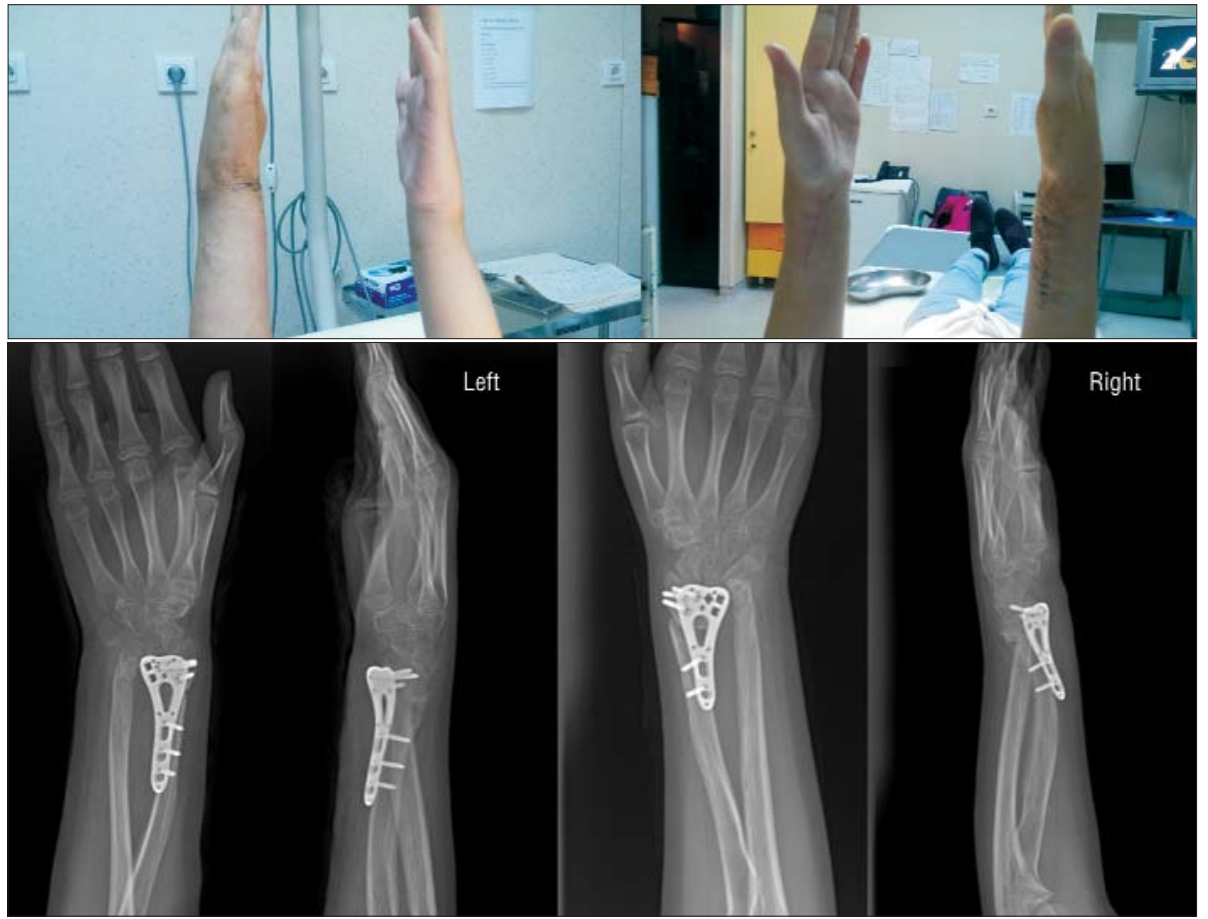

Figure 8. Postoperative result 


\section{Conclusion}

The case particularity consists of an anterior luxation of the distal ulna, which rarely seen and raises questions regarding the diagnosis and also the best suited surgical treatment. The surgical outcome is favorable, the patient no longer present pain and has an improved mobility of the forearm but still has a distal ulnar subluxation. Other surgical interventions, with very good results in most cases, like ulna shortening or distal ulna resection remain backup surgical solutions in case of distant recurrence of pain.

No conflict of interest to report.

\section{References}

1. Canale ST, Beaty JH. Campbell's Operative Orthopaedics, 12th ed. Philadelphia: Elsevier; 2012. p 3789-3792.

2. Abdelgawad A, Naga 0. Pediatric Orthopedics, 1st ed. New York: Springer; 2014. p 215-216.

3. Hefti F, Brunner R, Hasler CC, Jundt G. Pediatric Orthopedics in Practice. Berlin: Springer Medizin Verlag; 2007. p 652.

4. Zebala LP, Manske PR, Goldfarb CA. Madelung's deformity: a spectrum of presentation. J Hand Surg [Am]. 200732(9):1393-401.

5. Benson M, Fixsen J, Macnicol M, Parsch K: Children's Orthopaedics and Fractures, 3rd ed. New York: Springer; 2010. p 352-353

6. Herring JA. Tachdjian's Childrens Orthopaedics. Philadelphia: Elsevier; 2014. p 408-413.

7. Nordin M, Frankel VH. Basic Biomechanics of the Musculoskeletal System, 4th ed. Lippincott Williams \& Wilkins; 2012. p 366 - 380 